\title{
Developing pastoral therapy as a professional qualification in South Africa: Rationale and motivation
}

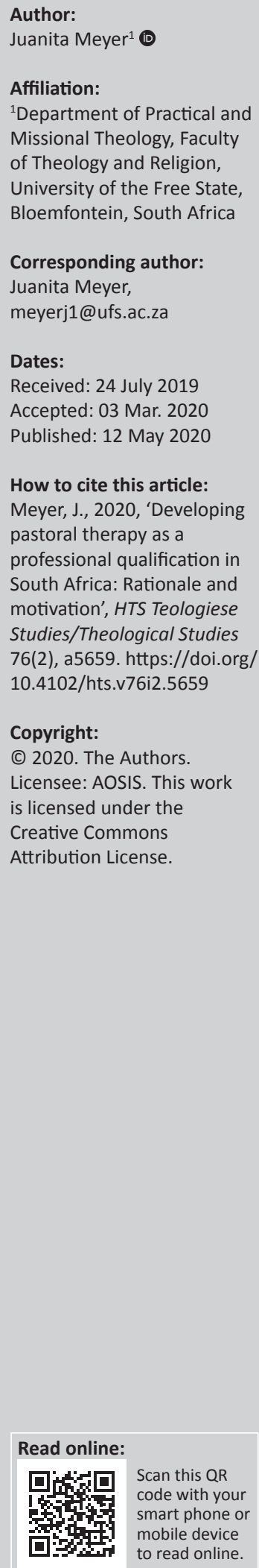

The professional training of pastoral therapists has been a topic of controversy for many years in South Africa. Up to date, the training of pastoral workers has been limited to the study of ministry and as such is limited by the primary aims and outcomes of this curriculum. In a postapartheid, post-colonial South Africa, the need for pastoral workers is intensified by the needs of community- and faith-based organisations for trained and registered therapists to alleviate the counselling needs of their beneficiaries on all social levels. This article discusses the current state of affairs of the training and curriculum related to the profession of pastoral therapy in the context of South Africa, the various sociopolitical and religious needs that are still left unanswered in the field, and makes recommendations for the registration and accreditation of the profession with a specific curriculum focused on multicultural, multi-spiritual and postmodern nuances. The author argues that such a curriculum, accredited by a statutory body, can operate as a national health resource, will be more cost-effective than other related health services and may transform the social justice landscape related to both the providers and beneficiaries of this type of care.

Keywords: Professionalisation of pastoral therapy in South Africa; Statutory body versus professional council or body; CPSC; SAAP and HPCSA; Ministry training; Social justice.

\section{Introduction}

The professional training of pastoral therapists has been a topic of controversy for many years in South Africa. Up to date, the training of pastoral workers has been limited to the study of ministry and as such is limited by the primary aims and outcomes of this curriculum. In a post-apartheid, post-colonial South Africa, the need for pastoral workers is intensified by the needs of communityand faith-based organisations for trained and registered therapists to alleviate the counselling needs of their beneficiaries on all social levels. More often than not, these organisations have to rely on volunteers or social workers (who are already overwhelmed by the number of social work-related cases), as they can neither afford to appoint a registered psychologist nor can they risk appointing someone without being aware of their level of qualification.

This article narrates the spectrum of needs in the sociopolitical and religious context of South Africa for the transformation and professionalisation of pastoral therapy, with the primary aim of social justice. The argument is made that the development of a professional qualification in - and the professionalisation of - pastoral therapy can provide the field with a multicultural, multispiritual and post-modern approach, which can function as a national health resource, can be more cost-effective in relation to other health services and can be a source of social justice and transformation.

\section{The current status of pastoral care and therapy training in South Africa}

In South Africa, formal training in pastoral care and counselling takes place primarily within the framework of ministry training. Postgraduate opportunities in pastoral care and training are available to either people in ministry who want to advance their skills within this field or laypeople who are in some way or the other related to a congregation and want to establish themselves as pastoral caregivers and offer care within the confines of their congregation. Informal training is also known to take place within various Christian church denominations but is generally understood as being parochial, in that the services offered are aimed at 'proclamation, deliverance from sin and a desire to sustain their denominational members' (Agbiji \& Agbiji 2016:9). As such,

Note: This article is published in the section Practical Theology of the Society for Practical Theology in South Africa. 
many congregants engage in parochial activities without having received any formal training. Agbiji and Agbiji (2016:2) attribute this phenomenon to the 'narrow conception of pastoral care', which tends to focus on the ecclesial context of the field only.

With reference to ministry training, these programmes are offered at six of the main universities in South Africa, for example the University of South Africa (UNISA), ${ }^{1}$ the University of Pretoria, ${ }^{2}$ the University of the North West, ${ }^{3}$ the University of the Free State, the University of Stellenbosch ${ }^{4}$ and the University of the Western Cape, ${ }^{5}$ at their specific Faculties of Theology and Religion. Exceptions to these are the UNISA, which has departments for various disciplines within theological and religious studies within the School of Humanities, and the University of the Western Cape, which has a Department of Religion and Theology, situated in the Faculty of Arts.

Four of these universities with Faculties of Theology and Religion offer church-related ministerial training on behalf of the mainline Christian denominations (e.g. the University of Pretoria, the University of the North West, the University of the Free State and the University of Stellenbosch) and are also supported financially and academically by the Synods and Curatoria of some denominations. Pastoral care and counselling are then offered as a module within the larger programme of ministerial training - on an undergraduate level - and is usually only offered from the second or third year of studies, as part of practical theological training.

The consequence is that during the five-year ministerial training (which includes the four-year BDiv programme and one-year MDiv programme) students are exposed to a maximum of three pastoral care and counselling modules, that is, if education takes place in the context of the Dutch Reformed or Reformed churches, as other denominations only require the completion of the BDiv programme. Subsequently, many ministers and other faith workers approach universities for postgraduate specialisation in pastoral care and counselling as an additional skill to their skill set. Ministers and faith workers are increasingly approached by congregants to offer pastoral guidance, care and, sometimes, counselling. At times these faculties offer short courses in pastoral care and counselling, aimed specifically at laypeople who offer their services as pastoral care workers to their congregations.

Additional to these universities are private institutions that offer specialisation in pastoral care and counselling. Some of these institutions are the South African Theological Seminary

1.See https://www.unisa.ac.za/sites/corporate/default/Register-to-study-through Unisa/Subjects-\&-modules/All-modules/Advanced-Pastoral-Care-and-Counselling\%E2\%80\%93-PTH4804.

2.See https://www.up.ac.za/practical-theology.

3.See http://theology.nwu.ac.za/.

4.See http://academic.sun.ac.za/theology/thesnaar.html.

5.See https://www.za.uwc.org/page/?title=Pastoral+Care\&pid=2489.
(SATS) ${ }^{6}$ in Bryanston and the Bible Institute of South Africa ${ }^{7}$ in Cape Town, both of which offer distance learning courses, and Coram Deo $^{8}$ with centres in Pretoria, George and Durbanville, which focus solely on pastoral therapy training.

\section{The professionalisation of the field: Professional bodies versus regulatory bodies}

It is important to emphasise the differences between a professional and regulatory body. A professional body is a membership organisation which acts in the interest of a single profession and its registered members. Such bodies are usually independent of control by a government and focus mainly on maintaining the professional standards of people who are granted entry to a specific profession. A professional body is mainly concerned with regulating the educational standards of the profession, by certifying specific courses and providing opportunities to its members in obtaining continuous professional development (CPD) credits, which meet the standards of an approved curriculum (cf. Higher Education Better Regulation Group [HEBRG] 2011:7).

In comparison, a regulatory body acts mainly in the interest of the public by regulating and controlling the professional activities of people in a specific profession. Many regulatory bodies are supported by parliament policies and regulations, and as such they hold the power to control and regulate the professional standards of a profession by developing accreditation standards of a corresponding curriculum, which grants or denies access to such a profession. Normally membership to this body is mandatory for obtaining a practising licence (cf. HEBRG 2011:9).

This authoritative body normally holds a single registry of practitioners who meet the standards of training and practice, as determined by their regulations, and as a consequence has the power to remove registrants who are deemed unfit or incompetent to practise. Unlike a professional body, a regulatory body acts in the interest of both their registrants and the general public, who become the so-called 'clients' of registered professionals. As such, they not only act on public complaints, enforce disciplinary procedures and remove registrants if necessary, but they can also act in the interest of a registrant in protecting them against unfair public disputes (cf. HEBRG 2011:9).

In South Africa, the first steps to developing a professional body for pastoral care and counselling were taken in 1991 when three organisations - the Association for Clinical Pastoral Work (1988), the Association for Pastoral Psychology (SAAPS) (1983) and the Association for Clinical Pastoral Education in Southern Africa (ACPESA) (1970) - were joined in forming the Southern African Association for 6.See https://www.sats.edu.za/undergraduate/certificate-in-christian-counselling/. 7.See https://www.bisa.org.za/index.php/home/list-of-lecturers-and-support-staff. 8.See https://coramdeo.co.za/pastoral-narrative-therapy-course/. 
Pastoral Work (SAAP). Before 1991 these three organisations existed and operated mainly in the training of pastoral care workers. The mandate of SAAP was to support pastors, lay counsellors and independent practitioners who operated in different contexts: hospitals, call centres, congregations, correctional services, the South African Police Force, the South African National Defence Force - and on a microlevel - that of families and wedded people (SAAP n.d.).

On 06 October 2017, the South African Qualifications Authority (SAQA) approved the application of SAAP - now known as 'the Council for Pastoral and Spiritual Counsellors' (CPSC) - to function under the auspices of the Association of Christian Religious Practitioners (ACRP) as a professional and specialist council for Christian Religious Practitioners. ${ }^{9}$ The approval and recognition of the field of pastoral care and counselling as a professional body registered with SAQA indicate that it is recognised under the ACRP as '[a] Professional Body is a body of expert practitioners in an occupation or profession resulting in learning in and for the workplace' (SAQA n.d.:n.p.; author's added emphasis)

It is worthy of taking note that the CPSC is not the registered SAQA body, but only an associate of the ACRP, which is the registered SAQA body. SAQA, as a qualifications authority, is 'a juristic person - that is an entity given a legal personality by the law'. The SAQA Board is a body of 12 members appointed by the Minister of Higher Education and Training (SAQA n.d.b) and is responsible for the development, maintenance and quality control of the National Qualifications Framework (NQF). In turn, the objectives of the NQF (as outlined in the National Qualification Framework Act No. 67 of 2008) (Republic of South Africa 2019) are to:

- to create a single integrated national framework for learning achievements

- facilitate access to, and mobility and progression within, education, training and career paths

- enhance the quality of education and training

- accelerate the redress of past unfair discrimination in education, training and employment opportunities.

It is clear from the above information that professional bodies registered with SAQA are concerned with the control and maintenance of educational standards of the specific profession, and not in terms of statutory (legal) objectives.

A professional designation is defined by SAQA as 'a title or status conferred by a professional body in recognition of a person's expertise and/or right to practice in an occupational field' (SAQA n.d.b). The ACRP offers a religious professional person, with four possible designations (cf. SAQA n.d.d), which are in the order of ranking:

- Advanced Religious Practitioner (ID 842)

- Religious Practitioner (ID 841)

- Religious Professional (ID 843)

- Religious Specialist (ID 844).

g.See https://www.cpsc.org.za/news-and-events.
Members of CPSC will, therefore, register as an affiliate of the ACRP, who are designated into one of the four abovementioned categories. It is important to note that a person is designated a broad religious professional or specialist status, not demarcated to specialisation in pastoral therapy or counselling. This status is also not statutory, in other words, undergirded by governmental and health legislature and does not offer a person with a practising licence. Therefore, the CPSC under the auspices of the ACRP can be regarded as a professional body. Although the CPSC and the ACRP are professional bodies involved in the educational regulation of the profession, they do not play a current role in the development of specific curricula for pastoral care and counselling. The opinion held is that this existing (and only) professional body - albeit for religious practitioners and specialists - should be included in the development of pastoral therapy programmes at various tertiary institutions, through their affiliate, CPSC.

In turn, the Health Professions Council of South Africa (HPCSA) is the largest regulatory body in South Africa for the control and regulation of any health-related profession. Twelve professional boards ${ }^{10}$ are registered with the HPCSA, which include Dental Assisting, Dental Therapy and Oral Hygiene; Dietetics and Nutrition, Emergency Care; Environmental Health; Medical and Dental (and medical science); Medical Technology; Occupational Therapy, Medical Orthotics, Prosthetics and Arts Therapy; Optometry and Dispensing Opticians; Physiotherapy, Podiatry and Biokinetics; Psychology; Radiography and Clinical Technology and Speech-Language and Hearing Professions.

On their website the HPCSA has published their main objectives as the promotion of 'the health of the population, determining standards of professional education and training, and setting and maintaining excellent standards of ethical and professional practice' (HPCSA n.d.a:n.p.). Unlike the ACRP, the HPCSA (n.d.a:n.p.) as a statutory and regulatory body can enforce the standards of the professional practice, as the registration of professionals with the body, 'in terms of the Act is a prerequisite for practising any of the health professions with which Council is concerned'.

The council guides and regulates the health professions in the country in aspects pertaining to registration, education and training, professional conduct and ethical behaviour, ensuring continuing professional development, and fostering compliance with healthcare standards. All individuals who practise any of the healthcare professions incorporated in the scope of the HPCSA are obliged by the Health Professions Act No. 56 of 1974 to register with the Council. Failure to do so constitutes a criminal offence (HPCSA n.d.a).

The differences, therefore, between the two bodies (ACRP and HPCSA) lie in the authority conferred to the body by national legislature. The 12 boards register under the auspices 10.See https://www.hpcsa.co.za/Professionals/ProBoards. 
of the HPCSA are forced to comply with the Health Professions Act No. 56 of 1974. It should be noted that it is not the HPCSA that confers a practice number to professionals, but rather the Board of Healthcare Funders of South Africa (BHF n.d.), which recognises the professional and statutory status of a certain profession or body, as stated on their website:

The Practice Code Numbering System (PCNS) of BHF is a list of unique practice billing codes for providers of healthcare services in South Africa, Namibia and Lesotho. The practice number, allocated to all registered healthcare providers is a legal requirement for the process of reimbursement of a claim to either a medical scheme member or service provider. (n.p.)

As such, the BHF does not recognise the ACRP as a regulatory body at the moment (perhaps because they are not considered as health-related in national legislature) and therefore the designates cannot obtain a practice number from this organisation. In the past, various professional pastoral therapists have approached the Board of Psychology, registered at the HPCSA, with the request of including a category of pastoral counselling under their auspice, with no success. Reasons given are varied and controversial.

As to be expected, a practice number is a sought after commodity. Not only because it validates the status of a professional, but because it also increases access to the profession as a beneficiary when the beneficiary is a member of a medical aid scheme or has access to this service through a national health facility which requires practitioners to have a practice number. Therefore, people are denied access to such a specified health service on the grounds that spiritual health is not recognised by the government, through the auspices of the HPCSA, and therefore not eligible for a practice number.

Additionally, the tariffs of the profession are regulated by the BHF, which ensures a marked related and affordable fee structure. Another benefit is the registration of a private practice with the $\mathrm{BHF}$, which provides credible exposure to the professional and acts as a business and therefore provides the sense of a stable source of income for the practitioner. We should keep in mind that this is not only about the beneficiaries of these services (although they do remain number one priority) but also about the people who set out to qualify them in a certain profession, if the finances they spend on study fees justify the professional status they may or may not attain. More than often, students are not educated into the possible career paths of a qualification, and the limitations to that qualification. Allowing students to invest financially in their future, although knowing that they would not be able to make a living from it, in my opinion, becomes an ethical issue.

Furthermore, statutory regulation is needed to provide licencing to pastoral therapists, much in the same way as the Curatoria legitimises ministers, thereby maintaining a list of registered and competent practitioners, with the power to regulate practices, and remove practitioners who are guilty of unethical conduct. The field then becomes accountable to a higher body and the public interests that they should serve. Additionally, statutory licencing legitimises the profession as a service supported by national health legislature, which ensures that citizens can exercise their right to access this service $^{11}$ through national health facilities.

The question therefore asked is, what advantages do an ACRP designation provide an affiliate, as opposed to an HPCSA registration?

An immediate answer is that SAQA is mandated to regulate only educational standards, whereas the HPCSA is concerned with the legal requirements of the health profession, especially concerning a code of conduct of professional therapists, and the ethics involved in practice. These regulations are set out and regulated by national legislature, through the statutory authorities of the professional boards registered with the HPCSA. As such, not only the therapist but also the beneficiary is represented and, possibly, protected by national law, in the case of any dispute. Professionals registered with the HPCSA are also required to write a national examination with a professional board where their knowledge and understanding of national policies are assessed. Only when such an examination is passed, a person is allowed registration with the HPCSA. ${ }^{12}$

The website for the CPSC is vague regarding their position as an affiliate of the educational accredited body, ACRP, and the limits of its authority to the educational standards regulation and control of the body (which also has its limits). Although the CPSC is certainly free to provide 'designates ${ }^{\prime 13}$ with a scope of practices and a code of conduct, it cannot on a legal level protect both the beneficiaries of such services and the religious practitioners registered with them. Additionally, the registration status obtained is situated with the ACRP (and not the CPSC), and the designation is not a 'counsellor' or 'therapist' designation, but rather a 'religious practitioner' or 'specialist' designation, depending on one's level of qualification (SAQA n.d.d). The result of this is that the designation does not necessarily demand specific and indepth training in the role and responsibilities of a pastoral therapist or counsellor. ${ }^{14}$

\section{The development of a statutory, regulatory council for pastoral therapy}

An argument is not made against the adequacy of the CPSC or the ACRP to provide pastoral therapeutic services, training and support to practitioners - in fact, the history of

11.The service referred to is pastoral counselling as addressed in this article. If spiritual health is regarded as a health issue (which I argue it should be), it should be a constitutional right to have access to alleviation services. A national health facility is a facility that offers healthcare - a hospital, a clinic, a doctor or in this case a therapist or counsellor through any national health institution.

12.See https://www.hpcsa.co.za/PBPsychology.

13. Not 'members'.

14.Although CPSC might screen for a counselling degree before accrediting a student, it is not required by the designation specifications. In this case the designation only warrants religious education training or theological training. 
SAAP and the CPSC emphasises awareness of the importance of adequate training of therapists and counsellors, and monitoring and control of the profession. The executive board of the CPSC demonstrates awareness of this imperative and has fought many battles to achieve this. Therefore, an SAQA registration is indeed an achievement to be proud of and paves the way for future developments. Instead, this article argues that a statutory status for the profession is required in positioning it firmly in the context of a healthrelated profession, as to adequately develop the field as such, control and monitor the activities of professionals, protect the rights of both the practitioner and beneficiaries of this service, and improve access to these services on a national-health level. ${ }^{15}$

Conversely, the researcher is of the opinion that registration with the Board of Psychology (HPCSA) is not the route to go, as psychology as a therapeutic field has a modern epistemology at its philosophical roots, and is still much informed by colonial discourse, which focuses predominantly on individual therapy. This biased focus ignores the collective health of the community and the influence of socio-cultural forces on the social justice that an individual in that community will experience. As such, psychological services are often only available to the privileged few who can afford these services.

Additionally, psychology, as an academic field, tends to be a-theological, and any attempt to amalgamate these two professions will rob the field of pastoral therapy from the 'purpose and nature of its call' (McClure 2010:238). A synergistic pastoral anthropology, as proposed by McClure 'understands salvation and healing as participation in cocreating the kin-dom of God, finding and being with God in profound social ways' (2010:238). This theological perspective, as stated by McClure (2010):

$[H]$ olds us responsible for joining the Divine Creator, Sustainer, and Redeemer in attending to the synergistic relationship between persons as well as the sociocultural and institutional threads that help make the fabric of our lives. (p. 238)

Although pastoral theology and practice should, in essence, be interdisciplinary - and in some instances transdisciplinaryand therefore, employing the wisdom of other knowledge regarding the human condition in its training, it is not an imitation of psychology and should not attempt to be a different form of psychology. Instead, the opinion is held that pastoral theology, as an academic field and praxis, and pastoral therapy, as a practice, falls in a health-related domain of its own. Therefore, it is argued that it should create a board of pastoral therapy under the auspices of the HPCSA, or should at least develop a statutory council, which has both educational and legal jurisdiction, recognised by BHF as a

15.This article argues for a notion of health which includes biopsychosocial an spiritual health, and also argues therefore that spiritual health should be regarded by the HPCSA as a health issue. The understanding of spirituality and its relation to religion are issues for religious institutions to discuss as it necessarily influence the education and training of a religious practitioner. It can therefore be argued that spirituality and religion are health issues, if health is seen to include the body, psyche, soul and its social component. health-related professional council (similarly to the function and status of the present Allied Health Professions Council).

As a health profession, pastoral therapy should be aimed at the alleviation of communal and community struggles, focused specifically on social injustices experienced by the community as a whole, and the individual as the product of that society. Pastoral therapy should never become privatised, as to exclude the already marginalised and disenfranchised. 'Privatisation' is used here as referring to those practices, which exclude the economically deprived and socially marginalised and disenfranchised from participating in, and having access to services, which can improve their general physical, psychosocial and spiritual health; thus, by improving the justice, they will experience in a particular society. It is, therefore, envisioned that a training programme for pastoral therapy is undergirded by specific ontological, epistemological and theological assumptions about the nature of people, the nature of the social and political reality of these people and our understanding of God and the healing salvation that God offers.

\section{Demarcating pastoral theology, care, counselling and therapy}

It has been established that pastoral therapy is not another form of psychology and, therefore, does not compete with psychological professions in the formation of its imperatives. As a result, it becomes important to differentiate between the different practices of pastoral theology, as to position pastoral therapy within a specific context of health.

Burck and Hunter (1990:867) contend that pastoral theology which forms the philosophical foundation of the practices of pastoral care, counselling and therapy - originates from the 'theology of shepherding'. Although contemporary pastoral theological theory has developed to include a wider perspective, the scholarly field of pastoral theology can be described as a 'branch of theology that is concerned with the basic principles, theories and practices of the caring and counselling offices of ministry' (McClure 2010:19). In praxis, pastoral theology aspires to reflect 'on concrete human experience with the explicit goal of formulating practical methods of dealing with problems or crises that can be used in the context of ministry' (McClure 2010:19-20). These methods are focused on the concepts of 'care' and 'healing' in a variety of individual and social contexts.

Pastoral care - a practice of pastoral theology - in turn, is the very basic practices of the care of the church (by its leaders and congregants), to support and nurture fellow believers in the daily contexts where they find themselves. It is focused on 'everyday expressions of care' and may include 'preaching, visitations, performing funerals, counselling parishioners, outreach to the homeless...' (McClure 2010:21), etc.

Another more formalised and specialised practice of pastoral theology is pastoral counselling. This practice includes the notion of 'to counsel' and 'to guide' the faith community 
and its members and is less bound to the ecclesia than pastoral care. This ministry of care is usually given to a person who expresses a specific concern or need, related to a specific experienced crisis (McClure 2010:21). More than often, this ministry is expressed on an individual level, as developed from the modern Western, psychological notion of 'individualism'.

Because of a lack of a proper definition of pastoral therapy, or the difference between pastoral counselling and therapy, the Greek language of the New Testament is consulted for a better understanding. It was deemed wise to search for relevant meanings as it was used in the Judeo-Christian tradition, which informs the field of pastoral care, and not psychology, with its roots in secular tradition. It was however not a simple task to search for a corresponding Greek verb for the English verb 'counselling', neither for the English noun, 'counsellor'. Nevertheless, an exploration of the New Testament Greek in terms of how they referred to a counsellor and (in the New Testament era) his role was fruitful.

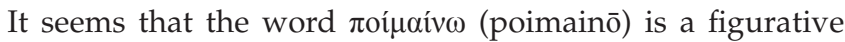
derivative of the word meaning 'shepherd'. As this word is used in Mathew 2:6, it is meant to refer to leading with the implication of providing for; to guide and to help; or to guide and take care of (cf. Louw \& Nida 1993:466). The noun

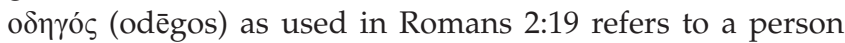
who guides or leads, and with special reference to this text, the 'blind' refers to those who are spiritually 'blind' and therefore requires guidance from someone with a proper understanding of the (spiritual) truth and corresponding behaviour (cf. Louw \& Nida 1993:466). According to Louw and Nida (1993:466), a word often used in those times was غ́лí (ēpitrēpō), but not specifically referred to in the New Testament, which indicates 'to instruct'. Galatians 4:2 uses the word غ́лí the supervision of those who take care of him and manage his affairs'. When the words غ́ $\pi i \tau \rho o \pi$ s (ēpitropos) and $\pi \alpha \iota \delta \alpha \gamma \omega \gamma o ́ \varsigma$ (paidagōgos) are used in a combined manner, it may indicate guiding, directing and showing concern for

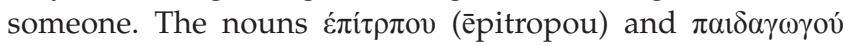
(paidagōgou) might, therefore, refer to a guardian, a leader and a guide. In considering these phrases and terms, and the contexts in which they were used in the Judeo-Christian tradition, the conclusion is made that 'pastoral care and counselling' might be the correct term to use when referring to the role of the pastor, or religious worker as someone who guides, who leads from behind and instructs when necessary. Instruction in this sense might then not only be focused only on crisis, but also on normative life issues with which the congregant might struggle with. Likewise, the word 'counsellor' is derived from the Latin noun, consiliator, which is derived from consilior ('I take counsel'), or from consilium, which indicates to plan, council, have wisdom or give advice (cf. Lewis 1891). The English Oxford Living Dictionary (online) describes a counsellor as 'a person who gives advice or counsel, especially on personal problems' and counselling as '[t]he provision of professional assistance and guidance in resolving personal or psychological problems'.

'Therapy' is a contentious word, used interchangeably with counselling in the context of psychological and spiritual care. In turning therefore to its Greek roots, $\theta \varepsilon \rho \alpha \pi \varepsilon v \omega$, -ió, $-\alpha \varsigma$ (therapeuo, -ia, -as) is used in Mathew 10:1 and Luke 9:11 to refer to the actions that 'cause someone to recover health, often with implication of having taken care of such a person', and therefore can be summed up as meaning 'to heal', 'cure' and 'take care of'. If considering the Judeo-Christian understanding of health as a holistic state of being, we can conclude that this can also refer to psycho-spiritual ill health. It should be remembered that psyche, in Greek, is qvon (psychē) and refers to 'the essence of life in terms of thinking, willing, and feeling' - 'inner self, mind, thoughts, feelings, heart, being' (Louw \& Nida 1993:321). In various passages (e.g. Phlp 1:27; Mt 26:38; Heb 12.3; Eph 6.6), the use of this word refers to 'the entire being of a person' (Louw \& Nida 1993:322), and a great injustice is done (as often happens in the social sciences) when one excludes its spiritual meaning. This is supported by Mathew 22:37 when its writer uses three distinct words in the following text: 'you shall love the Lord

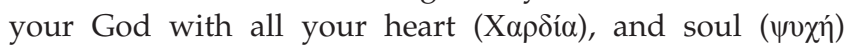

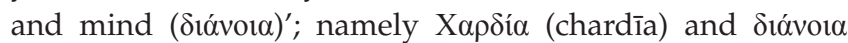
(dianoia); respectively meaning 'heart' (figuratively) with reference to 'inner self and mind' (Louw \& Nida 1993:320); and the ' psychological faculty of understanding, reasoning, thinking and deciding' (Louw \& Nida 1993:325), e.g. the mind. In supporting the holistic healing ( $\theta \varepsilon \rho \alpha \pi \varepsilon v i$ í) of the human, Louw and Nida (1993) state the following:

Because of the three terms, some have insisted that there must be at least three quite different parts of personality, these are only three different perspective which one may employ in thinking about or describing human personality. Still others would contend that the use of the three terms, X $\alpha \rho \delta i \alpha ; \psi v \chi \eta$ and $\delta$ ióvot $\alpha$, only emphasises the totality of human personality, and no clearcut distinctions can possibly be made. Certainly the referents involve considerable overlapping. (p. 322)

In interpreting these ancient understandings of the various roles of the pastor, or religious leader, it is argued that the praxis of pastoral theology can be separated into three categories, each with distinct roles and functions, each of which involves different levels of training:

- Pastoral care: the imperative and subsequent actions of all faith members to care for each other and the body of Christ through the various ministries of the church.

- Pastoral counselling: the role of a faith leader, who has been educated in theology to care for, guide and instruct the members of the faith in the behaviour and attitudes of the followers of Christ, not limited to instruction and guidance, but also include the support of the whole being of the person of faith, not only as an individual, but also in his or her community of believers and life.

- Pastoral therapy: a specialised form of care and cure, aimed at the healing of the wounded psyche and therefore, $\pi v \varepsilon v \mu \alpha \tau \chi x o s$ (pneumatichos - spirit), which includes the whole being of a person, referred to the 'mind', 'spirit' 
and 'soul', for a lack of a distinct and exact description. Care and cure might (and it is argued, should) take place in consideration of a specific society a person finds himself or herself in; and in collaboration with this the faith community and secular society.

\section{Pastoral therapy in South Africa, and for South Africans}

The remainder of the article argues for a specific type of pastoral therapeutic praxis, which addresses some of the main issues in the context of South Africa, as to provide adequate and relevant healing practices to the South African society.

\section{An argument for a decolonised pastoral therapeutic praxis}

McClure (2010:81) states that contemporary pastoral theological practices have been influenced by both the perspectives and practices of "'secular" professions and the medical model of practice' (which focuses primarily on the biological constitution of a human being). This focus has resulted in a loss of a pastoral identity in pastoral theology and practices, through the academic move from religious praxes to secularised praxes. The history of pastoral care and counselling has therefore shown a similar trend, as shown in McClure (2010):

[F]rom emphasis on religiously-based (especially Christian) seelsorge, or care of souls, to a turn toward the social scientific, especially psychological, lens as a primary means for understanding the human condition. (p. 81)

Already in 1951, McNeil (1951:319) has observed which is cited in McClure (2010) that:

[T] he 'empire of medical science' has risen as the dominant interpretive lens, rather than theology being the primary guide on the arts of care. (p. 81)

Clebsch and Jaekle (1967:14) support this, which is cited in McClure (2010), by stating:

$[I] \mathrm{n}$ the twentieth century the rise of 'non-pastoral professions' capable of caring for troubled persons mans that 'the ministry of pastoral care has fallen into the position of a junior partner to many other helping professions. (p. 81)

The era from the 1950s to the 2000s, therefore, saw a rapid change in identity concerning pastoral care and counselling, where pastoral care and counselling activities became more aligned with the praxes of a secular, medical, psychological paradigm and less aligned with religious communities, their specific pastoral needs and the foci of pastoral theology. It is argued that this has led to a growing trend in individualism, neglecting the role of society in the flourishing (or languishing) of the human being and the role of a community in the healing of psychospiritual 'woundedness'. Barbara McClure (210:182) specifically argues that these changes have led to the notion of 'the self against society', and therefore the Western notion of individualism, and that psychological care is solely focused on the individual and his or her interaction with significant relations. It does not recognise the complexity of identity formation, which is influenced by the 'complex dynamics of relationships that include institutions, culture, and dynamics and structures of power' (McClure 2010:182). As such, therapeutic methods included in the so-called pastoral counselling practices do not include the consideration of societal and institutional structures, or a liberal praxis of reconciling the individual with society and unjust practices.

South Africa, with a diverse population of culture and religion, and a history of violence, inequality and injustice, did not withstand these influences. The result is that the field of pastoral care and counselling is currently influenced by European and American norms and values, highly dependent on developments in modern psychology, and therefore still 'imposing biased solutions to a spectrum of personal problems' (Marsella 2015:vii). The consequences are - as Marsella (2015:vii) emphasises - the invalidation of a diverse spectrum of life experiences, which compels people 'to sacrifice their identities and histories in favour of pseudo adjustments to the dominant cultural traditions'.

One should remember that these consequences relate to a minority of the population, which has the privilege of accessing psychological or spiritual care - the majority of the South African population does not have access to (what I like to call, pastoral therapy; but is currently still referred to as pastoral counselling) through national health facilities, and are not in a financial position to access available private services. The few South Africans who are ministered to through their churches receive a parochial version of pastoral counselling as most ministers are not adequately equipped to engage in a specialised form of pastoral care and counselling or therapy.

In defence of psychological developments, Marsella (2015:vii) observes a growing interest in including multicultural theories in the training of practitioners. Multicultural counselling is defined as 'the responsibility and obligation of counsellors to understand and respond to the process and product of counselling in a multicultural society', attesting to the fact that the field provides adequate approaches with which biased, and narrowly defined counselling and psychological philosophies can be deconstructed (cf. Marsella 2015:1). Gorski and Goodman (2015:2) observe that more and more counsellors are exploring various practices which can assist them in coping better with the full diversity of the person they counsel, thereby creating a 'more equitable and just world' through their counselling practices.

It should be noted, however, that, multicultural notions within the praxis of pastoral care and counselling do not equate the decolonising reflection of theory. In many instances, multicultural care and counselling centralise culture to such an extent that oppressive phenomena become part and parcel of the culture; instead of addressing them as the power discourse and purposive societal engagements they are. The consequence to the practice is that power discourse (under the guise of culture) is tempered in such a 
manner that they reappear as a different form of marginalisation, not visible to the untrained eye (cf. Gorski \& Goodman 2015:2-3). This framework fools people into thinking that they are embracing diversity, although in reality no real power shifts are taking place (cf. Foro Educativo as cited by Aikman 1997 in Gorski \& Goodman 2015:3). Gorski and Goodman (2015:4) emphasise the fact that the interrogation of people's (often the privileged) own socialisation, their power and privilege in society and their complicity in systems of oppression are much harder to face and address than changing the language they use.

It is argued, therefore, that containment of the notion of unexamined 'multiculturism' can easily become another form of colonial ideology. Hernandez-Wolfe (2011:294) defines coloniality as 'the systemic suppression of subordinate cultures and knowledges by the dominant Eurocentric paradigm of modernity, and the emergence of knowledges and practices resulting from this experience'. As such, colonial ideology seeped into the language of every science globally, simplifying our understanding of complex phenomena. An example of such a simplistic understanding is colonial ideology's tendency to dichotomise and essentialise our understandings, such as, 'complex identity groups are homogenized in order to fit into simplistic identity development models' (Gorski \& Goodman 2015:5), evident from the multitude of 'textbooks' that explain how one can understand and summarise the main characteristics of each ethnic or cultural group. Instead, identities are experienced within a complex socio-political context, which inevitably influences people's psycho-spiritual well-being (cf. Gorski \& Goodman 2015:5).

As an alternative, a de- or post-colonial framework that employs the notions of social justice will be aware of the diversity within each ethnic, gender and sexual orientation group and acknowledges that not only race, culture, religious values and traditions influence the identity and life experiences of a person, but also that these identities intersect in ways that make some people - more than often from certain demographic histories - more vulnerable to be marginalised in society. An example is the tendency of helping professions (which include practices of care and counselling) in referring to marginalised groups as victims and therefore the objects of oppression, which become a social justice issue in much the same way with which experiences of being excluded from economic wealth, public participation and social cohesion are social justice issues. Gorski and Goodman (2015; cf. Brown 1995, Deepak 2011) reiterate the emphasis of such practices, which underevaluate the potential of the disenfranchised in creating their own liberation - taking from them in fact, the opportunity of self-liberation:

This seemingly good-intended advocacy places the focus on the practitioner as the 'do-gooder active agent', instead of focussing on these communities as having their own power and agency in the personal and collective struggle for freedom. (p. 6)
As Freire (2000, cited in Gorski \& Goodman 2015) pointed out:

[T]rue liberatory practices reject humanitarianism and approach that view someone experiencing oppression as a passive object; instead they embrace what he called humanisation, which focuses on one's own power and agency in the personal and collective struggle for freedom. (p. 6)

The challenge then for pastoral therapeutic practices, specifically, is to be a true source of recovery and healing by embodying decolonising thinking, wherein the client is liberated from the power of the dominant discourses imposed onto him or her by his or her society. Pastoral therapy, through a decolonised philosophy, should enable the client to explore, as stated by Marsella (2015) as:

$[T]$ he process of (1) who they are at this time, (2) how they have become the person they are, (3) and why there may be dissatisfaction and problems, pain, and suffering in their life. (p. vii)

This type of therapeutic relationship recognises that the distribution of power - also between the therapist and client - might be disproportionate, and that the therapist is responsible for considering his or her role as a source of power, being careful not to impose therapeutic measures entrenched with cultural-historic perspectives, which tolerate power discourses. The decolonised therapist would not only be concerned with cultural differences and identities, but also be highly sensitive to socio-cultural contexts, which are embedded with injustices related to the intersectionality of identities, such as race, class, gender, sexualities, culture, language and religion, and which either confine or advance access and opportunity (Marsella 2015:viii; Gorski \& Goodman 2015:7; cf. Hernandez-Wolf 2011).

\section{An argument for a pastoral therapeutic praxis that addresses contemporary African challenges}

In South Africa, an eclectic approach to pastoral care and therapy is often used by ministers, lay counsellors, and the so-called trained counsellor alike, and this differs substantially from the approaches and paradigms taught at universities and other academic institutions. In support of this observation, Nadine Bowers du Toit (2009:102) contrast the foci of academic intellectuals with those of religious practitioners (e.g. pastors, ministers, counsellors, etc.). Accordingly, academic intellectuals often focus on the contextualisation of cultures and religion and search for elements, which are relevant to the African culture, such as the practice of divination. Religious practitioners focus instead on the repercussions of contextualisation and how it relates to the specific needs of congregants, as they are responsible simultaneously for the satisfaction of the cultural needs of congregants and the sustenance of denominational (more than often, Western) religious practices. The result is an immense gap between the ventures of academics and the practices of minister and pastors on the ground, leaving the religious practitioner to tend to the multitude of needs, with little resources at his or her disposal. 
In support of this phenomenon Magezi (2016:5) asserts that, '[T]he African intellectual project does not reflect the needs and practicalities of church and pastoral care in life on the frontlines'; rather, in his opinion, the African believer is left to move continuously between the 'challenges posed by both African modernity and technology; and African tradition'. Meanwhile, scholars in the field remain preoccupied with creating a 'unique African identity (in opposition to the Western identity)', which results in an uncritical and romanticised notion towards 'African traditional culture and ideology' (Meyer 2020:n.p.; cf. Bowers Du Toit 2009:102).

African pastoral practitioners (who are most of the time also the only religious practitioner in one congregation) are often left to manage the challenges and disillusionment of congregants who experience daily disorder, injustices and oppression. Magezi (2016:4) accuses African scholarship of turning a blind eye to contemporary African challenges, influences of coloniality and Euro-American solutions to problems, although African pastoral theology is not progressing. The result is an uncritical and unsystematic reflection on the issues that plague Africans daily.

Meanwhile, Miller-McLemore (2005:102-103) argues for a pastoral theology - globally - where the present 'individualism' lens of focus is redirected to include the care of communities, thereby arguing for a pastoral theology that incorporates aspects of a public theology. This type of 'public' pastoral theology will focus on a systematic criticism of all cultural norms and practices (cf. Koppel 2015) in terms of how it contributes to social injustices. With this framework, the 'competitiveness' of world-views fades, although both their strengths and weaknesses are illuminated for the benefit of social and individual justice. In line with this, Magezi (2016:7) suggests that a pastoral theology for Africa, from Africa, should engage with 'contextual challenges and critically reflect on its theory as well as its contribution to global care rather than be narrowly focused'.

\section{An argument for pastoral therapy as a health imperative}

As previously mentioned the therapeuia of the psyche and pneumatichos of all members of the community should be a governmental imperative and be incorporated into national health strategies. The notion of health is not only an indicator of physical and psychological health but also refers to the development of people, who are in need of a holistic framework of care and support. Agbiji and Agbiji (2016:1) have found that environments fuelled with sickness and suffering can affect people's notions around meaning and purpose, which will inevitably contribute to the quality of their daily interactions and experiences. These experiences are both of psychological and spiritual importance.

The development of Africa is based on the extent to which people are healthy (bio-psycho-social-spiritual) and have access to various health services and the extent to which her people in interconnecting networks are empowered, and thereby transformed to engage in collective actions. According to African scholars Adogame (2013:107) and Agbiji and Agbiji (2016:4), Africa is in need of the so-called 'religious capital formation', which has the power to drive social justice and lead to the collective health of her people. Religious capital is built on the notion that people invest their time and their production into religious organisations to empower these organisations to improve the social standards of people's lives. In turn, religious capital formation is built on the concept of 'spiritual capital', which refers to the strengthening of 'relationships, norms and values' (cf. Adogame 2013:107; Agbiji \& Agbiji 2016:4). Religious and spiritual capital thereby becomes a form of social capital, which has been shown by various research to have the ability to eradicate poverty and human suffering which occurs in many forms (see Agbiji \& Agbiji 2016:1; Cochrane 2011:231-252; Schmid, Cochrane \& Olivier 2010:139-149; Ter Haar \& Ellis 2006:351-367; Wepener et al. 2010:61-82).

Jost and Kay (2010:1122) provide a definition for social capital's antecedent - social injustice - and accordingly, social capital can be divided into the localities of redistributive justice, procedural justice and interactional justice. In translating these to the terms that are applicable to South Africa, Chipkin and Meny-Gibert (2013:5) refer to these terms as 'economic justice, public participation and social cohesion'. Agbiji and Agbiji (2016:3) in turn incorporate these three imperatives for social capital (hence also religious capital) 'into the framework of a decolonial, transformative and liberative pastoral theology', as they argue that these imperatives entail value for the concept of health in Africa. Their argument is based on Cochrane's (2010:182) thesis that these assets can be the driving force behind health interventions. Because pastoral theology is regarded as a praxis, which reflects on the experience of lived religion as it is experienced during circumstances of illness, crisis and trauma, and also during social injustices such as the inaccessibility of proper healthcare for the poor, it can act as a source of empowerment, which 'through reconciliation helps to transform the powerless or sufferers for a better life by making them agents of change and not mere victims' (Agbiji \& Agbiji 2016:4).

Agbiji and Agbiji (2016:5) are of the opinion that the religious and spiritual resource of pastoral care, a social capital resource for health and healthcare, is underutilised in Africa, despite the tendency of Africans to be intrinsically religious or spiritual (cf. Adogame 2013:123). They assert that pastoral care as a religious health asset has the potential to provide dignity to people's religious and spiritual paradigms by providing them with the necessary care during the times of illness and crises, in collaboration with the healthcare services they receive (for example, during hospitalisations). Instead, African health systems are founded upon and driven by colonialist ideals which fail to fathom the relationship 
between the African notion of health and religion that characterise their worldview (cf. Agbiji \& Agbiji 2016:5).

Additionally, pastoral theological practices should incorporate the spiritual care of non-affiliates and even non-believers in straying away from the tendency to over-evangelise believers in the face of illness, crises and trauma (cf. Orton 2008:n.p). Such a professional approach to pastoral care - instead of a parochial approach - addresses the lived experiences of injustices and creates an inclusive approach to holistic health, which includes spiritual and religious capital such as 'advocacy, liberation, development and empowerment' (Agbiji \& Agbiji 2016:9).

\section{Conclusion}

\section{Remark}

The author of this article argues that pastoral theological praxis and its practices, specifically pastoral therapy, need professionalisation and development of its professional training programme with the emphasis on a unique ethos, which moves away from a colonial culture, to a multicultural, transformative and liberal, decolonised pastoral theology. Such theology is focussed on pastoral and spiritual care as a health resource, a pastoral therapeutic method, which is sensitive to the operation of power in contributing to social injustices and addresses contemporary African challenges.

\section{Acknowledgements Competing interests}

The author declares that she has no financial or personal relationships which may have inappropriately influenced her in writing this article.

\section{Author's contributions}

J.M. is the sole author of this research article.

\section{Ethical considerations}

This article followed all ethical standards for a research without direct contact with human or animal subjects.

\section{Funding information}

This research received no specific grant from any funding agency in the public, commercial or not-for-profit sectors.

\section{Data availability statement}

Data sharing is not applicable to this article as no new data were created or analysed in this study.

\section{Disclaimer}

The views and the opinions expressed in this article are those of the author and do not necessarily reflect the official policy or position of any affiliated agency of the author.

\section{References}

Adogame, A., 2013, African Christian diaspora: New currents and emerging trends in world Christianity, Bloomsbury Publishing, New York, NY.

Agbiji, E. \& Agbiji, O.M., 2016, 'Pastoral care as a resource for development in the global healthcare context: Implications for Africa's healthcare delivery system' HTS Teologiese Studies/Theological Studies 72(4), a3507. https://doi.org/10.4102/ hts.v72i 4.3507

Aikman, S., 1997, 'Interculturality and intercultural education: A challenge or democracy', International Review of Education 43(5-6), 463-479. https://www. jstor.org/stable/3445060?seq=1\#metadata_info_tab_contents

Association of Christian Religious Practitioners (ACRP), viewed 11 January 2019, from http://www.saqa.org.za/show.php?id=5658.

Board of Healthcare Funders (BHF), n.d., Practice Code Numbering System (PCNS) Division, viewed 11 January 2019, from https://pcns.bhfglobal.com/pcns-division.

Bowers du Toit, N., 2009, 'Theology and praxis: Friends, foes or mere acquaintances? A case study from Paarl', Journal of Theology for Southern Africa 133(March), 97-110.

Brown, W., 1995, 'Wounded attachments: Late-modern oppositional political formations', in J. Rajchman (ed.), The identity in question, pp. 199-228, Routledge, New York, NY.

Burck, J.R. \& Hunter, R.J., 1990, 'Pastoral Theology, Protestant', in R.J. Hunter (ed.) Dictionary of pastoral care and counselling, pp. 867-872, Abingdon, Nashville, TN.

Chipkin, I. \& Meny-Gibert, S., 2013, 'Introduction: New and contemporary spaces in South Africa', Social Dynamics 39(20), 151-158. https://doi.org/10.1080/0253395 2.2013.796126

Clebsch, W.A. \& Jaekle, C.R., 1967, Pastoral care in historical perspective, an essay with exhibits, Harper and Row, New York, NY.

Cochrane, J.R., 2011, 'A model of integral development: Assessing and working with religious health assets', in G. Ter Haar (ed.), Religion and development: Ways of transforming the world, pp. 231-252, Columbia University Press, New York, NY.

Council for Pastoral and Spiritual Counsellors (CPSC), n.d., 'The application to SAQA for professionalisation has succeeded', News and Events, viewed 11 January 2019, from https://www.cpsc.org.za/news-and-events/194-the-application-to-saqa-forprofessionalisation-has-succeeded.

Deepak, A.C., 2011, 'Globalization, power, and resistance: Postcolonial and transnational feminist perspectives for social work practice', International Social Work 55(6), 779-793. https://doi.org/10.1177/0020872811414038

Freire, P., 2000, Pedagogy of the oppressed, transl. M.B. Ramos, Continuum International Publishing Group, New York, NY.

Gorski, P.C. \& Goodman, R.D., 2015, Introduction: Toward a decolonized multicultural counselling and psychology', in R.D. Goodman \& P.C. Gorski (eds.) Decolonizing 'multicultural' counseling through social justice, Springer, New York, NY. https://doi.org/10.1007/978-1-4939-1283-4_1

Hall, S., 1996, 'When was the "post-colonial" thinking at the limit', in I. Chambers \& L. Curti (eds.), The post-colonial question: Common skies, divided horizons, pp. 242-260, Routledge, London.

Health Professions Council of South Africa (HPCSA), 2007, Health Profession Act 56 of 1974 , Health Professional Council of South Africa, Pretoria.

Health Professions Council of South Africa (HPCSA), n.d.a, About, viewed 11 January 2019, from https://www.hpcsa.co.za/About.

Health Professions Council of South Africa (HPCSA), n.d.b, Board of Psychology, Registration, viewed 11 January 2019, from https://www.hpcsa.co.za/ PBPsychology/Registration.

Health Professions Council of South Africa (HPCSA), n.d.c, Professional boards, viewed 11 January 2019, from https://www.hpcsa.co.za/Professionals/ProBoards.

Hernandez-Wolfe, P., 2011, 'Decolonization and "mental” health: A Mestiza's journey to the borderlands', Women and Therapy 34(3), 293-306. https://doi. org/10.1080/02703149.2011.580687

Higher Education Better Regulation Group (HEBRG) 2011, Professional, Statutory and Regulatory Bodies: An exploration of their engagement with higher education HEBRG, London.

Jost, J. \& Kay, A.C., 2010, 'Social justice: History, theory, and research', in S.T. Fiske, D. Gilbert \& G. Lindzey (eds.), Handbook of social psychology, 5th edn., pp. 1122-1165, Wiley, Hoboken, NJ.

Koppel, M.S., 2015, 'Practicing public pastoral theologies in contexts of difference', Journal of Pastoral Theology 25(3), 151-152. https://doi.org/10.1080/10649867. 2015.1123923

Lewis, C.T., 1891, An elementary Latin dictionary, Harper and Brothers, New York, NY.

Lexico, n.d., Counselling, viewed 24 January 2019, from https://www.lexico.com/ definition/counselling.

Louw, J.P. \& Nida, E.A., 1993, Greek-English lexicon of the New Testament based on semantic domains, The Bible Society of South Africa, Cape Town.

Magezi, V., 2016, 'Reflection on pastoral care in Africa: Towards discerning emerging pragmatic pastoral ministerial responses', In die Skriflig 50(1), a2130. https://doi.org/ 10.4102/ids.v50i1.2130

Marsella, A.J., 2015, 'Decolonization of mind and behaviour: A responsibility of professional counselors', in R.D. Goodman \& P.C. Gorski (eds.), Decolonizing 'multicultural' counseling through social justice, Springer, New York, NY.

McClure, B.J., 2010, Moving beyond individualism in pastoral care and counseling: Reflections on theory, theology, and practice, Cascade Books, Eugene, OR. 
McNeil, J.T., 1951, A history of the cure of souls, Harper, New York, NY.

Meyer, J., 2020, 'Investigating the nature of and relation between masculinity and religiosity and/or spirituality in a postcolonial and post apartheid South Africa', HTS Teologiese Studies/Theological Studies 76(1), a5663. https://doi.org/10.4102/ hts.v76i1.5663

Miller-McLemore, B.J., 2005, 'Pastoral theology and public theology', in E. Graham \& A. Rowlands (eds.), Pathways to the public square, pp. 95-106, Transaction Publishers, London.

Orton, M.J., 2008, 'Transforming chaplaincy: The emergence of a healthcare pastoral care for a post-modern world', Journal of Healthcare Chaplaincy 15(2), 87-106.

Republic of South Africa, 2019, National Qualifications Framework Amendment Act 2019, Government Printers, Pretoria.

Schmid, B., Cochrane, J. \& Olivier, J., 2010, 'Understanding religious health assets: Health as a lens on religion and development', in I. Swart, H. Rocher, S. Green \& J. Erasmus (eds.), Religion and social development in post-apartheid South Africa: Perspectives for critical engagement, pp. 37-52, Sun Press, Stellenbosch.

South African Qualifications Authority (SAQA), n.d.a, ID 1067, Registered professional designations, viewed 11 January 2019, from http://pbdesig.saqa.org.za/ viewProfessionalBody.php?id=1067.
South African Qualifications Authority (SAQA), n.d.b, Professional bodies and professional designations, viewed 11 January 2019, from http://pbdesig.saqa. org.za/.

South African Qualifications Authority (SAQA), n.d.c, Information, viewed 11 January 2019, from https://www.saqa.org.za/about-saqa.

South African Qualifications Authority (SAQA), n.d.d, South African qualifications authority professional body: ACRP - Association of christian religious practitioners, viewed 11 January 2019, from http://pbdesig.saqa.org.za/viewProfessionalBody. php?id=1067.

Ter Haar, G. \& Ellis, S., 2006, 'The role of religion in development: Towards a new relationship between the European Union and Africa', European Journal of Development Research 18(3), 351-367. https://doi.org/10.1080/095788 1060089340.3

The Southern African Association for Pastoral Work (SAAP), n.d., The history of SAAP, viewed 11 January 2019, from http://www.saap.za.net/about-saap/history.

Wepener, C., Swart, I., Ter Haar, G. \& Barnard, M., 2010, 'The role of religious ritual in social capital formation for poverty alleviation and social development. Theoretical and methodological points of departure of a South African exploration', Religion and Theology 17(1-2), 61-82. https://doi.org/10.1163/157430110X517924 